\title{
СПЕЦИФИКА И ПРОБЛЕМЫ ПРАВОВОЙ КВАЛИФИКАЦИИ НЕЗАКОННОЙ БАНКОВСКОЙ ДЕЯТЕЛЬНОСТИ
}

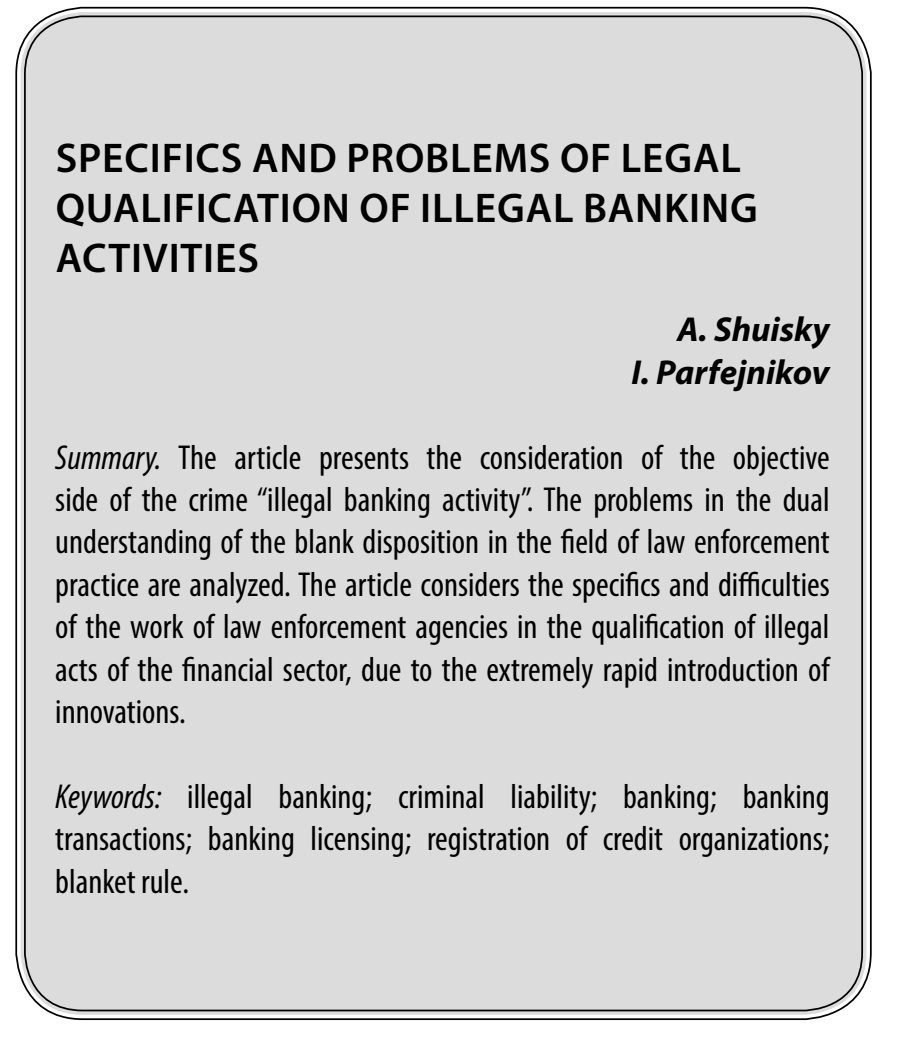

C овременная тенденция развития банковского сектора в структуре финансового рынка Российской Федерации, определенно характеризуется формированием таких условий функционирования, которые создают благоприятную среду для повышения в нем криминогенной опасности. Указанные условия связаны с повышением роли безналичных расчетов и общей интернетизации банковских операций, что с одной стороны, должно способствовать прозрачности проводимых операций, однако лишь усиливает нагрузку на правоохранительные органы ввиду инновационности способов правонарушений и методики их превенции и расследования. Как отмечает в своем заявлении Набиулина Э.С. «Незаконная банковская деятельность в последние годы становится наиболее «заманчивой» для организованных преступных групп. Банковская система в силу своей способности быстро и в любом объеме перемещать финансовые средства практически в любую точку мира весьма привлекательна для криминальных структур и, как следствие, особенно уязвима» [10]. Факт все большей распространенности преступлений в данной сфере общественных отношений, констатируют и многие исследователи.

\author{
Шуйский Андрей Сергеевич \\ К.ю.н., дочент, Институт сервиса, туризма \\ и дизайна (филиал) Северо-Кавказского федерального \\ университета в г. Пятигорске \\ ashuiskii@ncfu.ru \\ Парфейников Игорь Сергеевич \\ Доцент, Институт сервиса, туризма и дизайна \\ (филиал) Северо-Кавказского федерального \\ университета в г. Пятигорске \\ v.parfeynikov@yandex.ru
}

Аннотация. В статье представлено рассмотрение объективной стороны состава преступления «незаконная банковская деятельность». Проанализированы проблемы в двойственном понимании бланкетной диспозиции в сфере осуществления правоприменительной практики. Рассмотрена специфика и затруднения работы правоохранительных органов при квалификации противоправных деяний финансовой сферы, ввиду крайне быстрого внедрения инноваций.

Ключевые слова: незаконная банковская деятельность; уголовная ответственность; банковские операции; банковские сделки; лицензирование банковской деятельности; регистрация кредитных организаций; бланкетная норма.

Так Самойлова Ю.Б., Стаценко В.Г., указывают «Распространенность данного преступления обусловлена заинтересованностью большого круга предпринимателей в услугах, предоставляемых субъектами незаконной банковской деятельности. Ни для кого не секрет, что с целью вывода денежных средств из легального в теневой оборот многие организации пользуются услугами по незаконному обналичиванию и транзиту денежных средств. По оценкам Банка России и оценкам международных экспертов, использование наличных денег в объемах больших, чем это необходимо для обслуживания разумных, экономически обоснованных потребностей легальной экономики, является серьезным фактором риска легализации доходов, полученных преступным путем, уклонения от уплаты налогов и таможенных платежей, получения коррупционных доходов и финансирования терроризма, а ежегодные объемы обналичивания в России исчисляются сотнями миллиардов рублей.» [8].

В соответствии с вышесказанным, видится необходимым более детальная разработка существующих факторов повышения криминогенной опасности и правона- 
рушений в области реализации банковской активности, а так же их квалификации и расследования.

Основу квалификации преступных действий в банковской сфере регламентируется в соответствии со статьей 172 УК РФ. В данной статье закрепляются виды правонарушений, которые заключаются в двух вариациях: во-первых, это банковская деятельность, осуществляемая на безосновательной основе, то есть без соответствующей разрешительной документации, в виде регистрационных документов; во вторых, это осуществление банком допустимой деятельности, которая осуществляется в соответствии с назначением и целью банковского учреждения, однако сама деятельность является наоконной, в виду отсутствия лицензии (ст. 172 УК РФ) [1]. С точки зрения теории права, данный подход характеризуется выражением объективной стороны преступного деяния, что и подтверждается анализом диспозиции нормы права. Стоит отметить, что подобного мнения придерживаются многие исследователи, что нашло свое закрепление в комментариях к Уголовному кодексу Российской Федерации. Однако ни в самом кодексе, ни в комментариях к нему не дается развернутого и обоснованного анализа каждой из форм выражения объективной стороны преступного деяния с позиции бланкетного характера их рассмотрения. Дополнительной сложностью представляется неоднозначное понимание самого термина, поскольку, как пишет Кузнецов П.О. «В настоящий момент единого определения бланкетной диспозиции в науке уголовного права не разработано» [5]. Наумов А.В. предлагает определять бланкетную диспозицию в качестве как отсылку на норму права не уголовного характера, которая закрепляет признаки преступного деяния, противозаконность которого и определена нормой права, содержащей бланкетную диспозицию [7]. В свою очередь Михайлова И.А. основывает свою позицию, в вопросе бланкетной диспозиции, на обосновании одного или нескольких структурных элементов нормы уголовного права, посредством обращения к нормам права других отраслей, при уяснении содержащихся в них признаков [6]. Таким образом, основываясь на компаративном анализе мнения исследователей с буквальным толкованием 172 статьи Уголовного кодека Российской Федерации, можно прийти к выводу, что выражение объективной стороны правонарушений, связанных с незаконной банковской деятельностью, не раскрывается каждая из двух форм данного вида преступлений с позиции бланкетного характера их рассмотрения.

Стоит отметить, что поводом к формированию такого подхода со стороны законодателя, послужили ряд конструктивных и функциональных аспектов сферы регулирования, так как экономическая сфера общественных отношений в Российской Федерации - это многогранное явление. Общественные отношения в экономической сфере наиболее подвержены влиянию инноваций в самых разных аспектах. Связь, логистика, право и многое другое подвергается значительным изменениям со все большей скоростью и новые способы, и формы преступности не являются здесь исключением. Так же стоит отметить, что многие участники банковской сферы, во многом, имеют и международное значение. Особенно в странах бывшего СССР. Как отмечает Болт Ю.А. «Практика показала, что объективные процессы глобализации и международной интеграции, происходящие в мировой экономике, оказывают непосредственное воздействие на состояние преступности вообще и, в частности, в сфере экономики. Более того, наблюдается интернационализация преступности, идет процесс усложнения и многообразия схем совершения преступных деяний. Все это неизбежно порождает трудности при выявлении и раскрытии различных видов экономической преступности».[9].

Таким образом, ситуация в которой уголовное законодательство регулирует указанную сферу общественных отношений с позиций установления правил поведения для участников этих отношений, игнорируя при этом непосредственные формы данного вида правонарушений, представляется весьма обоснованной. В силу следования принципу максимальной превенции возникновения правых коллизий и пробелов, представляется нецелесообразным внедрять дублирующие нормы одновременно, и в уголовное, и в смежные отрасли права. Такой подход сделает законодательную базу слишком громоздкой, как для теоретического освоения, так и для правоприменительной практики. Данный постулат подтверждается и судебной практикой Конституционного суда Российской Федерации, где указанно «регулятивные нормы, устанавливающие те или иные правила поведения, не обязательно должны содержаться в том же нормативом правовом акте, что и нормы, не устанавливающие юридическую ответственность за их нарушение» [4]. Однако, по нашему мнению, не следует преуменьшать опасность двоякого толкования. Бланкетная диспозиция не содержит в себе прямой отсылки на соответствующие нормы иных отраслей права, поэтому существует опасность возникновения ситуации, когда норма-основание не только не является определенной, но и само понимание ее содержания различается в разных отраслях права. Эта ситуация крайне опасна и имеет серьезные негативные последствия для уголовного правоприменения на любых стадиях и особенно на стадии расследования и квалификации противоправных деяний. Одним из самых ярких примеров можно назвать ситуацию с осуществлением криптовалютных операций.

До вступления в законную силу Федерального закона от 31.07.2020 № 259-Ф3 «О цифровых финансовых 
активах, цифровой валюте и о внесении изменений в отдельные законодательные акты Российской Федерации» [3], осуществление банковских операций, с применением цифровых валют, проходило в ситуации серьезного правового пробела. Ситуация, в которой само понятие криптовалюта еще не нашло свое законодательное закрепление и регулирование этой области банковских операций было весьма затруднительно, создавало еще большие затруднения в сфере квалификации преступных деяний с оборотом криптовалюты, как уголовных преступлений. Так же, по нашему мнению, не следует игнорировать возникновение опасности все большего перехода криптовалютных операций в «теневой сектор». Увеличение объема денежного оборота «теневых» операций с электронной валютой, по причине невозможности осуществления таких операций на законных основаниях, не только способствует повышению криминогенной опасности в обществе, но и ставит перед правоохранительными органами нетривиальные задачи.

Подводя итог проведенного исследования можно прийти к выводу о том, что современная ситуация развития банковского сектора, характеризующаяся недостаточной разработанностью законодательного регулирования и перманентными инновациями в сфере оказания банковских услуг и осуществления операций, создают благоприятную среду для повышения в нем криминогенной опасности. В такой ситуации, правоохранительным органам следует проводить более серьезную работу в области надлежащей и своевременной квалификации совершенных противоправных деяний. А так же, усилить взаимодействие с органами законодательной власти Российской Федерации, с целью разработки более эффективных форм правового регулирования данной области общественных отношений.

\section{ЛИТЕРАТУРА}

1. Уголовный кодекс Российской Федерации от 13.06.1996 N63-Ф3 (ред. от 30.12.2020) [Электронный ресурс].— Режим доступа: http://www.consultant.ru/ document/cons_doc_LAW_10699/

2. Федеральный закон от 31.07.2020 N259-Ф3 «0 цифровых финансовых активах, цифровой валюте и о внесении изменений в отдельные законодательные акты Российской Федерации» [Электронный ресурс].—Режим доступа: http://www.consultant.ru/document/cons_doc_LAW_358753/

3. Федеральный закон от 31.07.2020 N259-Ф3 «0 цифровых финансовых активах, цифровой валюте и о внесении изменений в отдельные законодательные акты Российской Федерации» [Электронный ресурс]._- Режим доступа: http://www.consultant.ru/document/cons_doc_LAW_358753/

4. Определение Конституционного суда РФ от 21 апр. 2005 г. № 122-0 «06 отказе в принятии к рассмотрению жалобы гражданина Ионова Николая Владимировича на нарушение его конституционных прав частью 3 статьи 14.13 Кодекса Российской Федерации 06 административных правонарушениях» [Электронный ресурс]. Доступ из справ. правовой системы «Консультант Плюс» (документ опубликован не был); По жалобе общества с ограниченной ответственностью «Новгородский филиал «Содружество» на нарушение конституционных прав и свобод статьей 16.3 Кодекса Российской Федерации об административных правонарушениях: определение Конституц. суда РФ от 2 нояб. 2006 г. № 537-0 // Собр. законодательства Рос. Федерации. 2007. № 9.

5. Кузнецов, П.О. Бланкетные диспозиции: отдельные проблемные вопросы теории и практики / П.0. Кузнецов. - Текст: непосредственный // Государство и право: теория и практика: материалы III Междунар. науч. конф. (г. Чита, июль 2014 г.). — Т. 0.— Чита: Издательство Молодой ученый, 2014.—C. 70-72.

6. Михайлова И.А. Бланкетные нормы в уголовном законе и их применение органами внутренних дел: автореф. дисс. ... канд. юрид. наук. М., 2009. 28 с.

7. Наумов А.В. Российское уголовное право: курс лекций. В 2 т-х. Т. 1. Общая часть. 3-е изд., перераб. и доп. М.: Юрид. лит., 2004.496 с.

8. Самойлова Юлия Борисовна, Стаценко Вячеслав Георгиевич Особенности последующего этапа расследования незаконной банковской деятельности // Северо-Кавказский юридический вестник. 2015. № 2. URL: https://cyberleninka.ru/article/n/osobennosti-posleduyuschego-etapa-rassledovaniya-nezakonnoybankovskoy-deyatelnosti (дата обращения: 17.02 .202

9. Болт Ю.А. Взаимодействие органов внутренних дел государств - участников СНГ в рамках Координационного Совета руководителей органов налоговых (финансовых) расследований // Академическая мысль. 2019. № 2 (7). URL: https://cyberleninka.ru/article/n/vzaimodeystvie-organov-vnutrennih-delgosudarstv-uchastnikov-sng-v-ramkah-koordinatsionnogo-soveta-rukovoditeley-organov-nalogovyh (дата обращения: 18.02.2021).

10. Vystuplenie Predsedatelya Banka Rossii E.S. Nabiullinoy na konferencii «Aktual'nye voprosy realizacii gosudarstvennoy politiki v sfere protivodeistviya legalizacii (otmyvaniyu) dohodov, poluchennyh prestupnym putem, i finansirovaniyu terrorizma» 18 dekabrya 2013 goda [Elektronniy resurs].—Rezhim dostupa: http:// www.cbr.ru/pw.aspx?file=/press/press_centre/nabiullina_18122013.htm (data obrascheniya: 02.02.2015).

( ) Шуйский Андрей Сергеевич ( ashuiskii@ncfu.ru ), Парфейников Игорь Сергеевич ( v.parfeynikov@yandex.ru ).

Журнал «Современная наука: актуальные проблемы теории и практики» 